\title{
Religious-Socialistic Analysis of Land Ownership in Muslim Countries
}

\author{
Ridwan $^{1 *}$, Muhammad Fuad Zain ${ }^{1}$ \\ ${ }^{1}$ Sharia Faculty, IAIN Purwokerto, Purwokerto, Indonesia \\ *Corresponding author. Email: ridwan@iainpurwokerto.ac.id
}

\begin{abstract}
This paper aims to analyze the system of land ownership in Muslim countries with socialism-religious theory, based on ethics, morals, justice, and divinity. The data of this article refers to the sources of classical Islamic literature as a basic concept of land ownership in Islam and the practice of land law in several Islamic countries. The results of this study show three arguments; First, juridical-normative argumentation by proposing the theory of guardianship and inheritance, which states that the earth and its contents belong to God, which is controlled by the state as a representation of public interest. Second, historical arguments by submitting historical evidence about the policy of reforming land ownership laws, which are reflected in various state policies to regulate the acquisition, designation, use of land, and legal relations between the people and their land to represent the social principles of land. Third, the framework and practice of land law in various Muslim countries is based on two legal values, namely socialistic and religious.
\end{abstract}

Keywords: religious socialism, land ownership, Islamic law, regulation, land reform

\section{INTRODUCTION}

God created earth for all humans to apply their functions as the successors of the earth. Based on the theological dimension, Islamic law provides legal rules for the use of land functions in the form of certain restrictions. The natural resources exploration purposed for human life quality is the principal obligation as the successors. Everyone was commanded by God to utilize natural resources, assumed they have classes more than others [1].

In practice, successors function will be restricted by the State or political power, so that developed the concept of private and State ownership. Among the State's rights in terms of regulating land management are directly related to people's rights, namely ihyâ al-mawât, hima, and iqta' ' [2]. The State has the authority to restrict property ownership, revocation of property rights owned by private for public interest purposes [3]. There are opinions in Islamic jurists about the State's powers to regulate land ownership rights. Ibrâhim al-Khatib said three legal views. First, the restriction on property rights by the government is permissible. Second, not permitted for the government to restrict non-permanent property rights. Third, property rights restriction is not permitted by government policy [4]. The concept of the State authorities in the regulation of land ownership is debatable. al-Khâtib, al-Șadr, al-Zuhayly, alNabhâny divided property rights into; private property rights, public property rights, and the State property rights. Amir Kia argues that private property rights have restricted other individual interests [5]. al-Husaini argue the character of land ownership in Islam has resembled socialism, especially on abandoned or neglected lands, and land without owner whose status belongs to collectiveness under the State-controlled [6].
The reform of the land ownership system in Islam laid its foundation since the Prophet Muhammad and Caliphate have applied the structural political approach, wherein a land ownership law was positioned in public jurisdiction under the State power. The land reform policy in Islamic law is based on the public benefit value regulated by the State. It has the right to nationalize land ownership, land redistribution, administration of land ownership, restrictions on property rights, and revocation of land ownership rights.

The argument of the State authority to regulate a land ownership law is it's the most critical production factor which needed for the public interest. Hence, the State must control all federal benefits to ensure the social function of land to continue. This social-religious dimension of the area is a basis of the State policy that has been described in agrarian law practices in various Muslim countries.

\section{ETHODS}

Among Islamic thinkers, there are theoretical debates about land ownership rights. Some thinkers argue an and ownership rights in the Islamic economic system are positioned to Capitalism and Socialism, which recognizes in private and collective ownership. It's a middle ground both opposite views about land ownership in the modern world. This argument is thought of by Naqvi, al-Maududi, Kamal, Musa, Hussain, and Rahman. Different opinions aimed, according to Husaini, Șadr, and Ali Engineers, argue land ownership in Islam is communalistic under the State power. Husaini proposes the theory of inheritance, stating Allah is the landowner. Land ownership rights are just like an inheritance from God entrusts to humans.

The path of God's inheritance to humans can be obtained through peace or grants, conquest. The theory of inheritance 
and trusteeship of land ownership through conquest to the author is a keyword the birth of various land law instruments in Islam. For example, in the State's policy, to exploit the conquered land and to apply for the land reform programs. The process of inheritance is down from God to Moslems through a God Messenger. This opinion based on some evidence in Hadith asserted that:

"The land of the nation of 'Ad belongs to Allah and His

Messenger, and then the land belongs to you as a gift from me" [7]

According to Engineer suggests the theory of trusteeship stating God is the valid owner. Humans can own only as trustees that are allowed for welfare. They are treated as God's guardians in the industrial economic system with their land own [8]. While Bâshir insinuates Khilâfah theory (stewardship theory), proposing the theological dimension is an essential spirit of accountability from asset owners.[9] In substance, the îbasir method is the same as Engineer's theory.

Based on the above thinking framework, al-Husaini and Engineer concluded that a land ownership system in Islam is appropriate for an ownership system in Socialism, which believes land ownership is a collective property for Moslems regulated by the government. Similarly, Khafif, Qutb, and Sadr argue that land ownership in Islam is communalistic controlled by the country. Moreover, Iqbal supported the above opinion stating that individual property to all people is a source of crime [10].

The idea of Islamic socialism first emerged in the classical period initiated by Abu Dzar. He campaigned a need for equal wealth distribution to all people, and he condemns the state officials in centralistic wealth accumulation. When Mu'âwiyah, Governor of Syrian rename a nomenclature of Moslems wealth with God treasure, he protested it. He reasons that policy most potential to the assets be corrupted. As a result, he was exiled in al-Rubdhah until he died [11].

\section{RESULTS AND DISCUSSION}

\subsection{Land Property Rights Restrictions}

In Islamic law, the concept of private or collective property rights is not absolute. Private property rights must fulfill their social functions. Individual property rights must be subject to limitations of the benefit of others who are broadminded, namely the public benefit values. The government is a regulatory authority to regulate these limitations in the form of laws or qânûn (qayyûd al-qânûniyyat) [12]. That law was positioned as the legislation product that been formed as a social contract to justice guarantee. Justice terminology in the social contract is equal. John Borden Rawls defines the concept of justice as "justice as fairness," justice for every citizen. The state regulation of restriction on land ownership rights must be kind to principles of public interest creating [4]. Al-'Ibâdi makes some restrictions on the utility of property rights divided into four principles. First, not excessive in the efficiency of property rights. Second, Optimalisize in the utility of every property rights to the benefit of peoples. Third, how to obtain and utilize each property rights must refer to the rules of sharia law. Fourth, in the utility of property rights, not aggravate to the rights of others [4].

Correspondingly, al-Badri argues that sharia jurisprudence has not recognized the restriction of private property rights in quality and quantity, because its limit will affect the productivity value of the property rights that have been granted by God. Hence, this is contradictive with human nature. However, at the end of his writing, al-Badri stated that private property rights must be subjected to the state rules. The state can take over the individual property to the public interest, replaced with compensation. al-Badri's argument refers to the principle of fiqh that " it must prevent greater noxiousness then taking the smaller impact" [13].

The restriction concept of property rights in Islam was also conceived by Amir Kia, stating freedom of private property rights classified into two categories; The internal restriction, it is the Islamic rules. In an example, the obligation of zakat to private property ownership. The outer limits are the regulations made by the state. In the author's opinion, the division of land restrictions describes two official religions as the source of religiosity dimension and a country as the holder of political and legal authority.

Concerning ownership rights, Islam has outlined general views on six basics. First, Islam permitted a vast space for all people to obtain property ownership rights. Second, Islam has established the need to ascertain a social insurance system to help and empower the weak peoples. Third, Islam prohibits the monopolistic ownership practice for particular individuals or groups. Fourth, Islam does not preach material equality to all people because the Islamic principle recognizes the plurality of people in terms of character, abilities, and needs. Fifth, Islam advocates the need to build harmonious relations between individual and social interests. Sixth, Islam delineates asset management on the spiritual, ethical framework, principles of faith, and taqwâ [4]. In Islam, all peoples have the same opportunity to conduct an economic activity to produce and achieve profitability accordingly, as stated in the Qur'an, 4: 32. Mannan interprets the meaning of this verse is a fundamental concept of private property as an institution recognized in Islam. Private property has a very significant role in the development of capital productivity in various economic sectors to increase national income and individual welfare[14].

Private or individual ownership is a human nature that tends to possess the property for fulfilling basic needs such as eating, drinking, and surviving. At the same time, Islam also recognizes collective ownership. Thus, both individual and collective ownership institutions are recognized for their existence al-Khafîf, members of Majma' al-Bukhûth alIslamiyyat al-Azhar, argue private and collective ownership was not contradictory. Therefore, it is not permitted the public property to be owned in private ownership. On the other side, the state was forbidden to revoke an individual property right, in exception, have found the reasoning for public interest[15]. Fârûq al-Nabhâny also argues a private property cannot be confronted with collective property rights. Individual property rights and joint property rights must go hand in complement with each other[16]. Al-Khafif and al-Nabha's framework integrates the private and mutual interests inharmonious pattern of social relations. In this 
context, the state function in land regulation becomes very strategic as a mediator [17].

Revocating a private property right is legitimated to state if it was needed to the public interest. This policy concept analogous the case of expansion around Mosque Masjid alHaram on Caliphs Umar ibn Khatthab. Mosque Masjid alHaram cannot accommodate pilgrims. There is much building owned to private rights around it. He asked its owner to give up under state in expansion objectives of Mosque. Umar's policy impact debates in public, even some refused it. Then, Caliphs Umar takes over private ownership with political power and compensation fee. This model continues up to Caliphs Uthman ibn Affan, to expansion around Mosque Masjid al-Haram, he takes over private property with political power and compensation fee taken from Bayt al-Mâl [15].

This historical show that private land ownership is most respected its rights. The state, with its authority, can take over it for the public needs. From this case, it was also concluded that the acquisition of private property rights must be accompanied by compensation that was taken from Bayt al-Mâl. al-Khafif said if Bayt al-Mâl unable to pay, compensation fees are taken from people productive.

These historical facts also describe private land ownership is not absolute but restricted to the public interest. The scholars agreed that the authority to measures public interest is government as a mandate to regulate the peoples. However, the peoples to obey its decision. Therefore, alKhafif states that land ownership in Islamic law is more communal [15].

Like to al-Khafif, al-Shibâ'i proposes the state is justified to nationalize essential assets for the peoples living analogous Islamic with socialist principles. al-Siba'i said Islamic socialism is based on five human rights; rights to life, to freedom in its various forms, to obtain knowledge, to obtain dignity and ownership rights. Furthermore, al-Siba'i stated that a state could expropriate the private property in certain conditions such as disaster, famine, or when the country is in a financial crisis. Islamic socialism, according to him, is religious-socialism in morality that distinguishes elements of extreme socialism with its doctrine of resistance between classes [18].

Taha (1910-1985) insinuates the concept of ownership in Islam is collective or communal. According to him, capitalism is not the basic character of Islam [19]. Islam is closer to socialist economics. Socialism means everyone shares the same right in terms of wealth. The socialist system is an initial ownership system before the system established as a concept. The first person to popularize the term socialism in the modern sense was Robert Owen (1771-1858) around 1820. The word Communism was derived from the Latin word meaning "common" or joint ownership, which was first used by the French Revolutionary council in 1835 . The French Revolutionary Council believes that economic scaffolding will be built through the concept of joint ownership under the rule of the proletariat [19].

The idea of communism became a well-established theory formulated by Karl Marx (1818-1883). The essence of Marx's concept of communism (1818-1883) was based on four principles. First, historical discourse is determined by economic power. Second, class struggle. Third, the state is an instrument used by certain social classes to oppress other types. Fourth, violence or strength is nothing more than a tool for fundamental social change [19].

Thaha said Islam is more inclined to the socialist system. The clearest indicator is the obligation of zakat, which has a social dimension. Similarly, Bani Sadr, a Muslim thinker from Iran, also argued that Islam had conceptual economic closeness in terms of property rights with Marx's theory. Bani Sadr added that there is a different principle between the concept of property rights in Islam and Marxism. Marxism makes humans as the central to the creation of values and purpose in life. Meanwhile, Islam places God as the primary point of the establishment of rights. Consequently, one's own is not absolute. Hence, he proposes the monotheistic economics concept, as stated by Asghar Ali Engineer [8].

In Islamic Law, the basic principle of ownership is the transfer of rights based on the principle of ridâ (voluntary) as mentioned in Quran al-Nisâ', 4: 29. However, the revocation of property rights is possible without voluntary principles for the public benefit, to avoid more negative excesses compared to the specific and personal benefits. The legal issue for the revocation of private property rights into community property has always been a debate among the Ulama. The legal status for the repeal of individual property rights varies according to the situation and conditions. Islamic law generally recognizes that revocation of individual or community property rights is an unjustified act either by the state or by individuals.

Faruq al-Nabhany said the law of revoking property rights relatively depends on who and for what reason the revocation of the power was carried out. The repeal of property rights is likely to have three legal rights:

First, the revocation of individual ownership rights by the state based on the interests of the authoritarian authorities with the aim of enriching their control. Hence, according to the law, this act is $h$ nd constitute an act of persecution or illicit. Second, the revocation of property rights by the state to create an essential public benefit, such as for the construction of public facilities, for instance, expansion of public roads, and establishing hospitals. Hence, the law is undoubtedly possible. However, it must be ascertained the benefit in advance, to avoid unfair actions. Besides, it is also obligatory for the state to provide adequate compensation to the landowners. Third, the revocation of property rights by the state against all individual's assets obtained by violating the law and shara'. Included in the category of assets obtaining by violating the law is the assets obtained through business practices containing elements of riba, stockpiling of goods or property resulting from corruption or bribe. The law of revocation of this property by the state is justified in order to avoid losses by the wider community [16].

\subsection{Land Ownership Law in Several Muslim Countries}

Even though there are no similarities in the legal sources that underlie land law (agrarian law) practices in Muslim countries, in terms of legal principles, they share the nature of land ownership with the socialistic-religious dimension. In Muslim countries, each displays legal diversity according 
to their national experience and local needs. Some of the Muslim countries presented here as the samples are Indonesia, Iraq, Jordan, Syria, and Egypt. In Indonesia, the source of land law (agrarian law) refers to Law No. 5 of 1960 concerning Basic Regulations on Agrarian Principles, hereinafter abbreviated as UUPA. The primary source of material for national land law is based on traditional law as the fundamental law of the Indonesian people. The primary characteristics of traditional Indonesian law are religious communalistic.

The religious communalistic nature in UUPA is based on Article 1 paragraph 2 of the UUPA, which states that:

"All the earth and space, including the natural wealth contained within the territory of the Republic of Indonesia, as the gift of God Almighty, is the earth, water, and space of the Indonesian nation and is a national wealth.

Communalistic dimension of traditional law is represented with the concept of government land, which is the common land of the indigenous people, then adopted in the UUPA, stating that 'all land in the territory of Indonesia is the common land of the Indonesian nation (Article 1 paragraph 1)'. The religious dimension in the UUPA is indicated by the statement that "the earth and space, including the natural wealth, contained in it in the territory of the Republic of Indonesia, as a gift of God Almighty for the Indonesian people." The recognition of the gift of God Almighty is actually parallel with the first principle of Pancasila "Belief in the One and Only God" [20].

The religious dimension of the UUPA is also seen in several articles relating to the position of religious law as one of the basic considerations for making regulations in agrarian law. As stated in the Article 5 of the UUPA that traditional law is the source of national agrarian law which contains religious elements that have been reciprocated in the institution of traditional law. In article 14 paragraph 1 of the UUPA regulate the problem of the need for the government to provide land for places of worship and other sacred interests. Another article of the UUPA which regulates religious issues is the provision of protection of waqf land owned by religious institutions as stated in article 49 of the UUPA.

The influence of socialism in the development of the law is evident in several Islamic countries of the Middle East. In Iraq, for example, the economic activity empowering is divided into three sectors. First, the sector controlled by the state (socialist system). Second, the sectors controlled by the private sector. Third, economic sectors controlled together by the state and the private sector. Socialist sector, as in other countries (Algeria, Libya, and Syria), the Iraqi economy is dominated by centralized and socialistic systems, especially in the public sphere through national economic planning. The regulatory base used was the 1964 socialist law which regulates all banking and insurance activities [21]. In 1976, Algeria issued a National Charter of the Democratic People's Republic of Algeria calling on Muslim society to abandon feudalism, despotism and imperialism towards Islamic socialism.

In 1977, the Iraqi Revolutionary Command Council, through the Minister of Law, proposed a legal system reform (legal system reform), which clearly states that the basis for developing the country's economy is based on the development of a socialist society. The basis of the formation of Iraqi law is based on two sources; Islamic law (shari') as the source of primary law combining two schools of thought namely Sunni and Shi'i and adopting a modern legal system based on the Anglo-American Common Law and socialist systems [21].

The same thing applies to Jordan's agrarian law, which bases its law on Sharia and Ottoman land law 1858. In the Ottoman Land Code 1858, it is stated that there are two types of land; conquered land and land forfeited without war. In Jordanian land law, there are several terms of land ownership. First, the land of Mulk is an individual-owned land with absolute ownership. Second, the land of Miri, land owned by the Jordanian government, which is given to citizens as a place to live. The state has the right to take back the granting land if the land is not processed within 3 years, as stated in the Land law article 68. Third, the land of Waqf is the land destined for religious purposes (worship) and is a collective land. Fourth, Muwat land is dead land. Fifth, the land of Matruka is the land left by its owner whose purpose is for the public interest [21].

The legal source of the Jordanian state law is Islamic Law as stated in article 2 of the Constitution of Jordan in 1952. In the case of the land law, Jordan is heavily influenced or even adopts legal material from Ottoman law. Another Middle Eastern country that makes socialism as one of the official views of the country is the Syrian state. In the Syrian Land Law Article 3, paragraph 2 of the Syrian Constitution Decree in 1964, states that the primary source of the constitution is Islamic Law with a socialist perspective. In the 1964 constitution provision article 24 paragraph 2 stated that the basis of a socialist society is collective ownership for production. In Article 25 of the Syrian Constitution, it is stated that ownership is divided into; State ownership, Collective ownership, Private ownership [21].

Islamic socialism in Syria grew stronger when the $B a^{\prime}$ th Socialist Party came to power in 1963. At that time, the government carried out the nationalization of tribal land into state land. The government officially removes tribal property rights over land. Nationalization also penetrated dead land (al-mawat) acquired into state land [22].

A socialistic perspective on the practice of law in an Islamic state is also adopted in Egyptian agrarian law. In 1953 Egypt issued a regulation on land ownership, which set a maximum limit of land ownership of only 100 fedans $(0.405$ $\mathrm{km} 2$ ) as the revision of previously 200 fedans. Landowners who have more than 100 fedans, their rights are taken by the state, and the state has to provide compensation following the land taken at a predetermined time plus additional compensation in specific comparisons with the income that was obtained when they cultivated the land. According to the Egyptian fatwa council, limiting land ownership is intended for the owners to maximize their productivity and giving land rights to people who do not own land through $a$ land reform program [23]

The basic policy of property rights restriction in Egyptian agrarian law is avoiding monopolistic land ownership and the practice of landlords, which will cause oppression between landowners and their workers. Interestingly, this policy is created based on the legal policies made by the Khulâfa' al-Râshidîn, especially 'Umar ibn Khaththab's [24]. People's relations (individuals/groups) and the state in 
[2] A. H. al-Mawardi, Kitāb Al-Ahkām Al-Sultāniyyah.

terms of ownership, reach a point of harmony when wrapped with a strong legal basis. Ayatullah Mahmud Taliqani said the boundaries of property rights and economic relations are based on the harmony of three elements; individual, law, and state.

States, on its authority, can create legal regulations as references when a conflict of interest between individuals and society arises, or individuals with the state and society with the state. Law or regulation in such context is a normative structure refer to Ralph Linton's term (18931953) designs for living, which outlines what should be done or what should not be done by the citizens [17]. The term public interest (maslahah al-'ammah) in Western literature is known as the public benefit. While in the narrow sense, it is used to refer to public use, which is often interpreted as public access. The concept of public benefit/ public use is always related to the procurement of various public facilities for common interests as part of government programs in the context of state development [25].

The discussion of public interest in the context of development requires land reflects of legal relationship between the community as an individual and the state as the holder of political and legal authority in the country. To avoid tensions between individual relations in terms of property rights, it is important for governments to make regulations to regulate social order based on public benefits. The government's right to regulate land issues in fiqh is based on the theological justification of the Qur'an, about the political function of uwlil al-amr in regulating people's lives. The state is an authoritative institution to control and ensure the social function of land by giving legal restrictions on property rights.

\section{CONCLUSION}

From the above explanation, it can be concluded: First, land ownership in Islam based on the principle of justice by eliminating monopoly ownership that leads to feudalistic culture. The shifting paradigm of an exploitative feudalistic ownership system is shifted to a communalistic-religious ownership system under the state authority based on the principle of justice for mutual benefit. Second, the position of land ownership in Islam is more public dimensional because land issues concern the lives of many people and become an essential instrument in economic and religious activities. The state, as the public institution, has the authority to create various regulatory instruments to regulate land issues. Third, the framework and practice of land law in various Muslim countries are based on socialistic and religious. The socialistic dimension of the land can be seen in the functional aspects of the land besides functioning economically. Whereas the religious dimension is seen in the source of ownership, which comes from God's mandate to manage and use the land for the welfare of humanity.

\section{REFERENCES}

[1] Al-Qur'an al-Karim. Bandung: Syamil Publishing, 2012.
Beirut: Dâr al-Fikr, 2002.

[3] W. al-Zuhayly, Wasitatat al-Islâm wa Simahâtuhu. Damaskus: Kulliyâh Syari'ah Jamî'ah Dimasqa, 1989. [4] M. I. I. al-Khâtib, Al-Nizâm al-Iqtisâdy fí al-Islâm. Riyâd: Maktabah al-Haramain, 1989.

[5] A. Kia, "A Non-Technical Primer on Private Ownership in Islam.," J. Bus. Inq. Res. Educ. Appl., vol. 6, no. 1, 2007.

[6] S. A. N. A. al-Husaini, Al-Milkiyyat fi al-Islâm. Kairo: Dâr al-Shuruq, 1989.

[7] A. B. al-Baihâqy, Sunan al-Bayhâqy al-Kubrâ, 6th ed. Beirut: Dâr Ihyâ al-Turâth.

[8] A. A. Engineer, Islam and Liberation Theology: Essay on Liberative Element in Islam. Yogyakarta: Pustaka Pelajar, 2003.

[9] A. Hameed M. Bashir, "Property Rights, Institutions and Economic Development: An Islamic Perspective," Humanomics, vol. 18, no. 3, pp. 75-91, 2002.

[10] P. Tahir, "Poverty, Feudalism, and Land Reform The Continued Relevance of Iqbal," Pak. Dev. Rev., vol. 41, no. 4, pp. 967-972, 2002.

[11] M. ibn J. al-Tabari, Tarîkh al-Rusul wa al-Muluk, 2nd ed. Beirut: Dar al-Fikr, 1987.

[12] G. H. Tâha, Haq al-Milkiyyat. Kuwait: Al-Jami’ah al-Kuwait, 1977.

[13] A. 'Azîz al-Badry, Hukm al-Islâm fî alIshtirâkiyat. Madinah al-Munawwarah: Dâr al-Kutub al-Ilmiyyah, 1987.

[14] M. A. Mannan, The Making of Islamic Society: Islamic Dimensions in Economics Analysis. Cairo: International Association of Islamic Banks, 1984.

[15] 'Aly Al-Khafîf, Al-Milkiyyat al-Fardiyyat wa Tahdiduha fi al-Islâm. Kuwait: Dâr al-Kuwaytiyah, 1969.

[16] M. F. al-Nabhâny, Mabâdi' al-Thaqafati alIslâmiyyat,. Kuwait: Dâr al-Kutub al-'Ilmiyah, 1974.

[17] S. Soekanto, Pokok-Pokok Sosiologi Hukum. Jakarta: Rajawali, 1980.

[18] M. al-Sibâ'i, Islam dan Pembaharuan: Ensiklopedi Masalah-Masalah. Jakarta: RajaGrasindo, 1995.

[19] M. M. Taha, The Second Message of Islam. New York: Syracuse University Press, 1987. 
[20] B. Harsono, Hukum Agraria Indonesia: Sejarah Pembentukan Undang-undang Pokok Agraria, Isi dan Pelaksanaannya. Jakarta: Djambatan, 2007.

[21] S. H. Amin, Middle East Legal Systems. London: Royston Limitted, 1985.

[22] G. Rae, J., Arab, G., Nordblom, T., Jani, K., and Gintzburger, "Tribes, State and Technology Adoption in Arid Land Management, Syiria," Washington, D.C., 15,2006
[23] M. N. Siddiqi, Role of the State in the Economy: An Islamic Perspective. United Kingdom: The Islamic Foundation, 1996.

[24] J. L. Esposito and J. P. Piscatori, "Democratization and islam," Middle East J., vol. 45, no. 3, pp. 427-440, 1991.

[25] M. S. Sumardjono, Tanah dalam Perspektif Hak Ekonomi, Sosial, dan Budaya. Jakarta: Kompas, 2008. 